\title{
Effect of Different Media on Short Term Storage of Leaping Mullet (Liza saliens (Risso, 1810)) Sperm
}

\author{
Serhat Engin ${ }^{1, a, *}$, M. Kürşat Fırat ${ }^{1, b}$, Osman Özden ${ }^{1, c}$, Cüneyt Suzer ${ }^{1, d}$, \\ Müge Hekimoğlu, ${ }^{1, e}$, Onurkan Antepli, ${ }^{1, f}$, Şahin Saka ${ }^{1, g}$ \\ ${ }^{1}$ Aquaculture Department, Faculty of Fisheries, Ege University, 35100 Izmir, Turkey \\ *Corresponding author

A R T I C L E I N F O
Research Article

Received : 23/12/2019
Accepted : 16/02/2020 \\ A B S T R A C T \\ The present study aimed to evaluate the activation characteristics of the leaping mullet spermatozoa \\ and diluted with four different media (D1, D2, D3, D4) for $250 \mathrm{~h}$ at $4 \pm 2^{\circ} \mathrm{C}$. The semen was collected \\ from nine wild fish in Homa Lagoon, İzmir, Turkey in July, during reproductive season. In each trial \\ $(n=9)$, semen samples were collected and mixed to reduce sperm quality variation to obtain the \\ required gametes for the experiment. The semen was activated with natural seawater (salinity of 34 , \\ $\mathrm{pH} 7.9$ and $4 \pm 2^{\circ} \mathrm{C}$ ) to determine: motility time, motility rate and viability of sperm. Dilution with \\ inactivation media 1:3 increased motility time of diluted semen than control group. At the end of the \\ experiment, no significant difference was found for the duration of survival in the D2 and D4 groups. \\ Keywords: \\ The highest survival rate was found in D2 group.
}

Short - term storage

Liza saline's

Leaping mullet

Sperm

Viability

serhatakademik@gmail.com c-osman.ozden@ege.edu.tr e@muge.hekimoglu@ege.edu.tr g@sahin.saka@ege.edu.tr

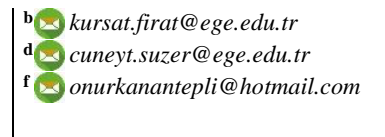

(iD) https://orcid.org/0000-0003-1470-209X
(i) https://orcid.org/0000-0003-3535-2236
(iD) https://orcid.org/0000-0002-7242-8925

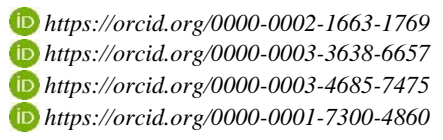

This work is licensed under Creative Commons Attribution 4.0 International License

\section{Introduction}

In aquaculture, prolonged cryopreservation of fish semen using extender and cryoprotectants is limited to only 40 to $50 \%$ of cellular protection (Watson, 2000). Therefore, storage of fish sperm at temperatures above freezing point and without the addition of cryoprotectants has been successfully used for a long time (McNiven et al., 1993). Short-term preservation techniques are an easy technique that allows the use of sperm to fertilize the eggs at various time intervals and provide more productivity during reproduction time. It can also help improve the genetic quality of the resulting offspring, as well as allowing the examination of sperm properties by facilitating sperm use by more males per female (Ciereszko and Dabrowski, 1994). The cooling of semen to temperatures close to $4^{\circ} \mathrm{C}$ is one conservation technique, wich prolongs temporal viability of undiluted semen from a few hours to days. This can be explained by reduction of spermatozoa's metabolic activity at temperatures below the physiological range.
The leaping mullet belonging to the Mugilidae family is widespread in a wide area that includes the Pacific and Atlantic oceans. Third world countries, South East Asia, Saudi Arabia, Gulf region countries and Eastern and Southern Mediterranean commercial cultivation of this species from the length of finger are made. The leaping mullet is a species that is often hunted in lagoons. In recent years, the lack of good breeding and uncontrolled hunting has led to a decrease in the population of this species.

The cooling of semen to temperatures close to $4^{\circ} \mathrm{C}$ is one conservation technique, which prolongs temporal viability of undiluted semen from a few hours to days. This can be explained by reduction of spermatozoa's metabolic activity at temperatures below the physiological range (Effer et al., 2015). In previous studies, short term preservation of sperm was performed in sea bass and bream (Barbato et al., 2003, Engin et al., 2018). Although there are short-term storage studies for the species Lisa persia, Mugil cephalus and Mugil liza belonging to the Mugilidae family (Chao et al., 
1974; Sukuraman et al., 2003; Magnotti et al., 2016), there are no study for Liza saliens. Therefore, this study is the first record. The present study aimed to evaluate sperm viability in fresh semen and in semen diluted with different media during short-term storage at $0-4^{\circ} \mathrm{C}$.

\section{Materials and Methods}

\section{Broodstock}

The experiments were carried out during the natural spawning period (i.e. July 2018) on sexually mature Leaping mullet $(380.2 \pm 21.1 \mathrm{~g}$ and $31.3 \pm 7.3 \mathrm{~cm}$, for weight and length, respectively) originating from Homa Lagoon (İzmir/Turkey). New harvested dead fish (n: 9) were used in the study.

\section{Collection of Gametes}

For semen collection, the abdominal and genital areas of each individual were cleaned with deionized water and dried with paper towel. After gentle abdominal pressure, semen was collected with $2 \mathrm{~mL}$ syringes and immediately stored in an ice-cold container at $4 \pm 2^{\circ} \mathrm{C}$ protected from light. The extracted semen was collected with a sterile syringe (without needle) and transferred in containers stored at a constant temperature of $4^{\circ} \mathrm{C}$ to Ege University, samples with urine or blood were discarded.

\section{Evaluation of Fresh Semen}

Sperm motility

Sperm motility (mot) was activated according to the procedure previously described by Valdebenito et al., (2017) with some modifications. Briefly, $1 \mu \mathrm{l}$ of semen was diluted in $3 \mu \mathrm{l}$ of $90 \%$ sea water $(\mathrm{pH} 7.0)$ on a slide and evaluated by subjective ex-amination using a phasecontrast microscope (Olympus $\mathrm{C} \times 31$ ) at $40 \times$ magnification. Motility time was measured with a stopwatch from the moment of activation until the total stoppage of all spermatozoa. Motility was classified into five categories, determining the percentage of actively moving spermatozoa: $1=0$ to $<5 \% ; 2=5-25 \% ; 3=25-50 \%$; $4=50-75 \% ; 5=75-100 \%$ (Cosson et al., 2008). Each sample was analysed in triplicate. Only samples with high motility ( $\geq 80 \%$ ) were used in this study.

\section{Sperm concentration}

Sperm concentration was determined in a Neubauer haemocytometer according to the criterion of Figueroa et al. (2013).

\section{pH and osmolarity}

Each sample was analysed in triplicate. subsequently, and due to the low volume of semen produced by each male $(<0.5 \mathrm{ml})$, a pool was prepared. Merck $\mathrm{pH}$ indicator $(5.5$ to 9.0) paper was used for sperm $\mathrm{pH}$.

In each trial $(n=9)$, to obtain the gamete quantities required for the experiment, semen samples were pooled (with a minimum of six males), in order to reduce the variability in sperm quality inherent among males (DeGraaf and Berlinsky, 2004).

\section{Experimental Design}

In each trial $(n=9)$, to obtain the gamete quantities required for the experiment, semen samples were pooled, in order to reduce the variability in sperm quality inherent among males (DeGraaf and Berlinsky, 2004). The semen pool was divided into five groups: 1) Control: undiluted semen; 2) treatment 1 (DS1): diluted semen in Hepes in a ratio of $1: 3$ semen: diluent $(\mathrm{v} / \mathrm{v}) ; 3)$ treatment 2 (DS2): diluted semen in DMSO in a ratio of 1:3 semen: diluent $(\mathrm{v} / \mathrm{v}) ; 4)$ treatment 3 (DS3): diluted semen in BSA in a ratio of 1:3 semen: diluent $(\mathrm{v} / \mathrm{v}) ; 5)$ treatment 4 (DS4): diluted semen in Tris in a ratio of $1: 3$ semen: diluent $(\mathrm{v} / \mathrm{v})$; at $4^{\circ} \mathrm{C}$ and in the dark with constant stirring during 11 days. The stored samples were analysed at hourly.

\section{Statistical Analysis}

Results from spermatological characteristics are given as mean \pm SD. The variance homogeneity of the data was performed using Levene's test. Differences among groups, data were compared by one-way ANOVA, followed by Tukey multiple range test a when significant differences were found at a 0.05 level. All measurements were carried out in triplicate.

\section{Results}

\section{Fresh Semen Characteristics}

Milt of $M$. cephalus is highly viscous, white in colour and the quantities of milt varied among individuals. Length-weight relationship of Liza saliens is $\mathrm{W}=$ $0.0449 \mathrm{~L}^{2.6201}\left(\mathrm{R}^{2}=0.88\right)$ (Figure 1).

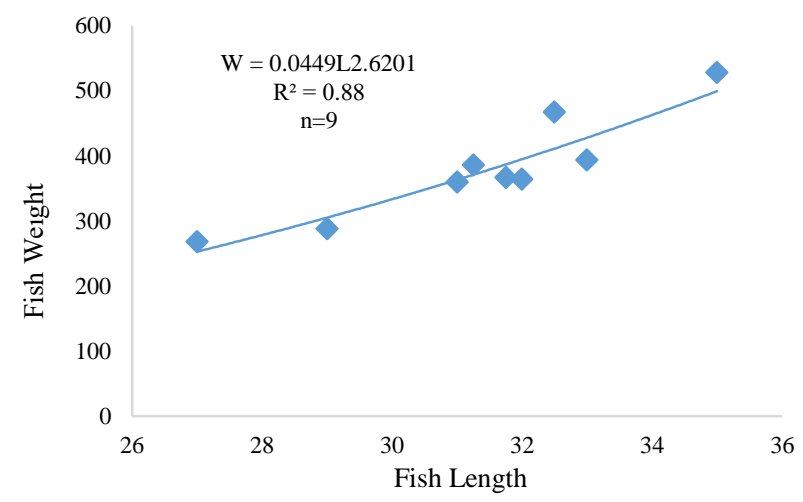

Figure 1. Length-weight relationship of Liza saline's

The parameters in fresh semen were: duration of sperm motility $=80.9 \pm 1.5 \mathrm{~s}$; sperm concentration $=14.0 \pm 8.9 \times 10^{9}$ spermatozoa $\mathrm{ml}-1$ and $\mathrm{pH}=6.7 \pm 0,2$. The average volume of sperm was determined as $4,46 \pm 0,72 \mathrm{ml} \cdot \mathrm{kg}^{-1}$. The highest and the lowest sperm volume was $5.88 \mathrm{ml} . \mathrm{kg}^{-1}$ and 3.17 ml. $\mathrm{kg}^{-1}$, respectively. The length-weight relationship of $L$. saline's with sperm volume is given below (Figure 2).

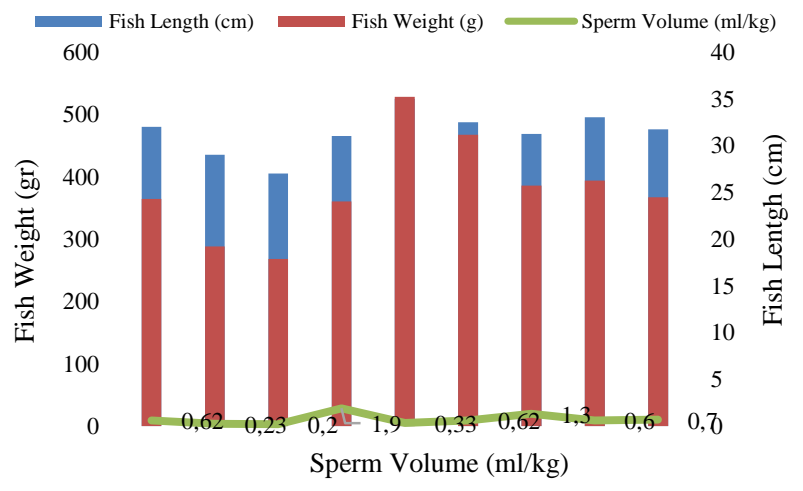

Figure 2. Length-weight relationship with sperm volume of Liza saline's 


\section{Evaluation of Sperm Function}

Sperm motility

There were no significant differences in sperm motility between the DSI, DS2 and DS3 groups at the time of the first activation $(\mathrm{P}>0.05)$. At the second days, motility decreased significantly in the fourth group and the control group (mot $=10 \pm 2,82 \%$ ). From day 4 to 8 sperm MOT decreased significantly in diluted semen (DS2: $55.8 \pm 2.8 \%$ to $10.1 \pm 2.0 \%$ and DS3: $70.3 \pm 1.5 \%$ to $38.7 \pm 8.5 \%$, respectively, Figure 3). End of the study highest motility on DS3 group. Sperm of undiluted samples was immotile at 2 day of storage.

Figure 3 Effect of short-term storage on sperm function of undiluted and diluted semen $(1: 1 \mathrm{v} / \mathrm{v}$ and $1: 3 \mathrm{v} / \mathrm{v})$ of Leaping mullet (L. saline's) for 8 days at $4^{\circ} \mathrm{C}$.

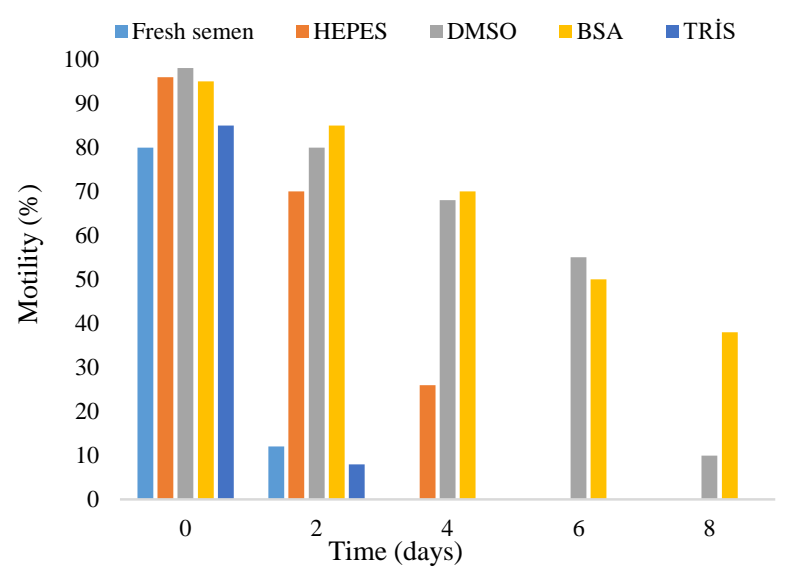

Figure 3. Effect of short-term storage on sperm function of undiluted and diluted semen $(1: 1 \mathrm{v} / \mathrm{v}$ and 1:3 v/v) of Leaping mullet (Liza saline's) for 8 days at $4^{\circ} \mathrm{C}$.

\section{Discussion}

The results of this study indicate there may be a method to effectively short term storage and maintain the viability of Liza saliens sperm. For this purpose, the average weight of $753.6 \pm 47.21 \mathrm{~g}$, the average length of $40.60 \pm 1.14 \mathrm{~cm}$ in the natural breeding period from the rootstocks identified as a natural breeding period, without any hormonal intervention was taken by the milking method. In a different study, it was determined that the sperm volume is higher in male fish which has hormone application, while there is no statistically significant difference in sperm motility, concentration and survival (Basavaraja and Hegde, 2005). It has been reported in previous studies that storage at low temperatures has a negative impact on sperm motility, viability and function ((Aguilar-Juárez et al., 2014; Aramli, 2013; Shaliutina et al., 2013; Trigo et al., 2015). In our study, a significant decrease in motility was observed after storage and the results were in parallel with previous studies.

As in other species, it is important to know the $\mathrm{pH}$ of the sperm in the fish to be applied to the sperm (Akçay et al., 1995; Suquet et al., 1993). In this study, many researchers in the measurement of semen $\mathrm{pH}$ (Suquet et al., 1993; Billard and Cosson, 1992; Cevik et al., 2000; Hatipoglu et al., 2007) as in the $\mathrm{pH}$ range of 5.5-9.0 indicator papers were used. The $\mathrm{pH}$ of the sperm obtained in the study was found to be 6,7 .
In previous studies, it was reported that by Astuirano et al. (2001) and Fauvel et al. (1999), sperm viability of cultured sea bass was found around 0,6-2 and 0,7-2,9 min under culture conditions. Additionally, this period was reported 0,4-2 and 3,6 $\mathrm{min}$ for Oncorhynchus mykiss (Yanagimachi et al., 1992; Billard, 1983). In Sparid, it was estimated 1,5-2 min for white sea bream, Diplodus sargus (Lahnsteiner and Patzner, 1998), 2,6-3,9 min for P. pagrus (Mylonas et al., 2003) and 1-3 min for sharpsnout sea bream, Diplodus puntazzo (Taddei et al., 2001). Besides, currently it was $6,9 \pm 0,8$ min for sea bream and also in other cultured marine fish, Psetta maxima, 3 different periods for viability of sperm were reported as 3-5 min (Dreanno et al., 1999), 1-17 min (Suquet et al., 1994) and 2-3 min (Chauvaud et al., 1995). It is well reported that viability of sea bream (Sparus aurata) sperm was determined as $6.9 \pm 0.8$ min (Engin et al., 2018). There is no study about this species for survival times of sperm. In our study, It is determine that the survival times of the leaping mullet sperm; $6 \mathrm{~min}$ in fresh sperm, $6.5 \mathrm{~min}$ in Hepes, 5 min $20 \mathrm{~min}$ in BSA, 3 min $20 \mathrm{~min}$ in Tris and $8.5 \mathrm{~min}$ in DMSO.

Dilution of milt in an extender is an important step for improving the quality of sperm after collection in aquatic animals (Ciereszko et al., 2000; Bobe and Labbe, 2008). Further, dilution ratio determines the success of short term preservation of milt at low temperature and production of fingerlings during fertilisation. In the present study, short term preservation of sperm in Liza saline's 1:3 dilution was found to be the best compared to other dilution ratios. Motility grade of spermatozoa decreased at higher dilution ratios probably indicating that all the intrinsic substances present in the seminal plasma, for example protein, glucose and ions loses their role at higher dilution (Jimenez et al., 2004; Mommens et al., 2008).

For cryopreservation, sperm membrane may be damaged after freezing and thawing procedure. All these processes negatively affect sperm fertilization capacity. After cryopreservation, sperm cell membrane, mitochondria, chromatin structure and acrosome may be damaged. Most of these damages were between -10 and $-40^{\circ} \mathrm{C}$ (Cabrita et al., 2007). As a result of the short-term storage protocol, sperm samples will be transported to the laboratory environment in order to determine the effects of the factors mentioned in reproduction biology. In our study, at the end of the experiment, no significant difference was found for the duration of survival in the control and DS4 groups $(\mathrm{P}>0.05)$. The highest survival rate was found in DS3 group.

\section{Conclusions}

In previous studies, it was reported that short term storage for Mugil cephalus and Liza parsia (Chao et al., 1974; Balamurugan et al., 2016; Sukuraman et al., 2003). But there is no study about Liza saline's therefore it is a first record for short term storage. However, further studies are required to improve the sperm motility for longer storage period at low temperature by modifying the extender composition. The data generated from sperm quality studies from the fresh milt will be useful for effective management of cryopreservation of gametes for captive seed production in hatcheries. 


\section{Acknowledgements}

This study is supported by Ege University Scientific Research Projects Coordination Unit. Project Number: 2018/SÜF/007.

\section{References}

Aguilar M, Ruiz G, Carmen C, Chávez G. 2014. Cold storage of the sperm of the endemic trout Oncorhynchus mykiss nelsoni: a strategy for short-term germplasm conservation of endemic species. Revista Mexicana de Biodiversidad Volume 85, Issue 1, March 2014, Pages 294-300. doi: https://doi.org $/ 10.7550 / \mathrm{rmb} .36352$

Akçay E, Tekin N, Seçer S. 1995. Balık spermasının prezervasyonu. Ege Üniversitesi Su Ürünleri Fakültesi Su Ürünleri Dergisi. 12 (3-4): 367-373.

Aramli MS. 2013. Retracted: ATP Content, Oxidative Stress and Motility of Beluga (Huso huso) Semen: Effect of Short-Term Storage. Reproduction in Domestic Animals https://doi.org/ 10.1111/rda.12339.

Balamurugan R, Munuswamy N. 2016. Assessment of sperm quality and short term preservation of sperm in Grey mullet Mugil cephalus (Linnaeus, 1758). Indian J. Fish. 63: 140144. doi: 10.21077/ijf.2016.63.4.61001-23

Barbato F, Canese S. Moretti F. Misiti S. Laconi F. and Rana K. 2003. Preliminary experiences for cryopreservation of Sparus aurata and Diplodus puntazzo semen Technology of Aquaculture in the Mediterranean p: 281-287.

Basavaraja N, Hedge SN. 2005. Cryopreservation of the endangered mahseer (Tor khudree) spermatozoa: Effect of extender composition, cryopreservation, cryoprotectant, dilution ratio and storage period on post thaw viability. Cryobiology. 2004 Oct;49(2): 149-56. doi: 10.1016 /j.cryobiol.2004.05.007

Billard R. 1983. Ultrastructure of trout spermatozoa: changes after dilution and deepfreezing. Cell and Tissue Research, 228; 205-218.

Bobe J, Labbe C. 2008. Chilled storage of sperm and eggs. In: Cabrita E, Robles V, Herraez P. (Eds.), Methos in reproductive aquaculture: Marine and freshwaterspecies Taylor and Francis, London (UK).

Cabrita E, Robles V, Rebordinos L, Sarasquate C, Herraez M.P. 2007. Evaluation of DNA damage in rainbow trout (Oncorhynchus mykiss) and gilthead sea bream (Sparus aurata) cryopreserved sperm Cryobiology 50: 144-153. doi: 10.1016/j.cryobiol.2004.12.003

Chao NH, Chen HP, Liao IC. 1974. Study on cryogenic preservation of grey mullet sperm. Aquaculture, 5(4): 389406. doi: 10.1016/0044- 8486(75)90058-7.

Chauvaud L, Cosson J, Suquet M. and Billard R. 1995. Sperm motility in turbot, Scophthalmus maximus: initiation of movement and changes with time of swimming characteristics. Environ. Biol. Fishes 43, 341-349. doi: 10.1007/BF00001167

Ciereszko A, Dabrowski K. 1994. Relationship between biochemical constituents of fish semen and fertility: the effect of short-term storage. Fish Physiol. Bioch., 12, 357-367. doi: 10.1007/BF00004300

Ciereszko A, Glogowski J, Dabrowski K. 2000. Biochemical characteristics of seminal plasma and spermatozoa of freshwater fishes. Cryopreservation in Aquatic Species. Tiersch TR, Mazik PM, Editors. World Aquaculture Society, p. 20-48. Baton Rouge, Louisiana. doi: 10.1007/s10695-005$4742-8$

DeGraaf JD, Berlinsky DL. 2004. Cryogenic and Refrigerated Storage of Rainbow Smelt Osmerus mordax Spermatozoa. Journal of The World Aquaculture Society, Vol. 35, No. 2 June. Doi: https://doi.org/10.1111/j.1749-7345.2004.tb01076.x
Dreanno C, Cosson J, Suquet M, Seguin F, Dorange G, Billard R. 1999. Nucleotide content, oxydative phosphorylation, morphology, and fertilizing capacity of turbot (Psetta maxima) spermatozoa during the motility period Molecular Reproduction and Development 53: 230-243. doi: 10.1002/(SICI)1098-2795(199906) 53:2<230: AIDMRD12> 3.0.CO;2-H

Effer B, Figueroa E, Augsburger A, Valdebenito I. 2015. Sperm biology of Merluccius australis: sperm structure semen characteristics and effects of $\mathrm{pH}$, temperature and osmolality on sperm motility. Aquaculture 408-409, 147-151. doi: https://doi.org/10.1016/j.aqrep.2018.05.002

Engin S, Firat K, Saka Ş. 2018. Short Term Storage of Gilthead Sea Bream (Sparus aurata, Linneaus, 1758) Spermatazoa and Investigation of Spematological Characteristic with Parental Relationships. Turkish Journal of Agriculture 6(3): 372-379, 2018. doi: https://doi.org/10.24925/turjaf.v6i3.372-379.1756

Fauvel C, Suquet M, Dreanno C, Zonno V, Menu B. 1999. Cryopreservation of the sea bass (Dicentrarchus labrax) spermatozoa in experimental and production simulating conditions Aquat. Living Resour. 11: 387-394.

Figueroa E, Risopatrón J, Sánchez R, Isachenko E, Merino O, Isachenko V, Valdebenito I. 2013. Sperm vitrification of sexreversed rainbow trout (Oncorhynchus mykiss): effect of seminal plasma on physiological parameters Aquaculture, 372-375 (2013), pp. 119-126. doi: 10.1016/j.aquaculture. 2012.10.019

Jiménez MF, Puchades S, Mocé E, Viudes-de-Cartro MP, Vicente JS, Rodriguez M. 2004. Use of Powdered Egg Yolk vs Fresh Egg Yolk for the Cryopreservation of Ovine Semen. Reproduction in Domestic Animal, 39, 438-441 2004. doi: https://doi.org/10.1111/j.1439-0531.2004.00537.x

Lahnsteiner F, Patzner RA. 1998. Sperm motility of the marine teleosts Boops boops, Diplodus sargus, Mullus barbatus and Trachurus mediterraneus Journal of Fish Biology 52, 726-742. doi: https://doi.org/10.1111/j.1095-8649.1998.tb00816.x

Magnotti C, Cerqueira V, Lee-Estevez M, Farias JG, Valdebenito I, Figueroa E. 2016. Cryopreservation and vitrification of fish semen: a review with special emphasis on marine species. Reviews in Aquaculture, 10(1): 15-25. doi: 10.1111/raq.12145.

McNiven MA, Gallant RK, Richardson GF. 1993. Fresh storage of rainbow trout (Oncorhynchus mykiss) semen using a nonaqueous medium Volume 109, Issue 1, 1 January 1993, Pages 71-82. doi: https://doi.org/10.1016/0044-8486(93)90487-J

Mylonas C, Papadaki M, Divanach P. 2003. Seasonal changes in sperm production and quality in the red porgy (Pagrus pagrus L.) Aquaculture Research 34, 1161-1170. doi: 10.1046/ j.1365-2109.2003.00922.x

Shaliutina A, Hulak M, Gazo I, Linhartova P, Linhart O. 2013. Effect of short-term storage on quality parameters, DNA integrity, and oxidative stress in Russian (Acipenser gueldenstaedtii) and Siberian (Acipenser baerii) sturgeon sperm. Anim Reprod Sci 139, 127- 135. doi: 10.1016 /j.anireprosci.2013.03.006.

Sukumaran S, Noble D, Gopalakrishnan A, Sanil NK. 2003. Ultrastructural changes in the spermatozoa of the goldspot mullet Liza parsia (Hamilton-Buchnan) in different diluents during cryopreservation. J. Mar. Bio. Ass. India 45 (1): 4753.

Suquet M, Dorange G, Omnes M.H, Normant Y, Le Roux A, Fauvel C. 1993. Composition of the seminal fluid and ultrastructure of the spermatozoon of turbot (Scophthalmus maximus) Journal of Fish Biology, 42: 509-516. doi: https://doi.org/10.1111/j.1095-8649.1993.tb00355.x

Suquet MR, Billard R, Cosson J, Dorange G, Chauvaud L, Mugnier C, Fauvel C. 1994. Sperm features in turbot Scophthalmus maximus: A comparison with other freshwater and marine fish species. Aquatic Living Resources, 7; 283294. doi: https://doi.org/10.1051/alr:1994031 
Taddei AR, Barbato F, Abelli L, Canese S, Moretti F, Rana J, Fausto AM, Mazini M. 2001. Is cryopreservation a homogeneous process? Ultrastructure and motility of untreated, prefreezing, and postthawed spermatozoa of (Diplodus puntazzo C.) Cryobiology 42: 244-255. doi: https://doi.org/10.1006/cryo.2001.2328

Trigo P, Merino O, Figueroa E, Valdebenito I, Sánchez R, Risopatrón J. 2015. Effect of short-term semen storage in salmon (Oncorhynchus mykiss) on sperm functional parameters evaluated by flow cytometry. First International Journal of Andrologia. doi: 10.1111/and.12276.
Valdebenito I, Cosson J, Contreras P, Sánchez JC, Oliveira RPS, Risopatrón J, Farías JG, Figueroa E. 2017. Spermatological research of experimentally farmed Patagonian blenny (Eleginops maclovinus) (Perciformes: Eleginopsidae) in Chile. Aquac. Res. 48 (8): 4197-4204. doi: 10.1016 /j.anireprosci.2018.08.019

Yanagimachi R, Cherr GN, Pillai MC, Baldwin JD. 1992. Factors controlling sperm entry into the micropyles of salmonid and herring eggs. Development, Growth \& Differentiation 34: 447-461. doi: https://doi.org/10.1111/j.1440-169X.1992. 00447.x

Watson PF. 2000. The causes of reduced fertility with cryopreserved semen. Anim Reprod Sci 60-61:481-492. doi: 10.1016/s0378-4320(00)00099-3 